\title{
Parkinson's transplant therapy faces setback
}

\section{Erika Check, Washington}

An experimental technique that uses transplanted fetal tissue to treat Parkinson's disease is not yet ready for widespread use, according to a study published online last week.

In the study, surgeons transplanted nerve tissue from aborted fetuses into the brains of patients with Parkinson's disease. The disease destroys neurons that produce the chemical dopamine, which is required for normal brain function. The transplanted tissue is intended to replace these damaged cells.

But the average condition of the 23 patients who received the treatment did not improve significantly compared with a group of 11 who did not have it. The researchers, led by Warren Olanow of the Mount Sinai School of Medicine in New York, measured whether the treatment affected the symptoms of the disease, such as muscle tremors, speech and mental abilities (C. W. Olanow et al. Ann. Neurol. 54, doi:10.1002/ana.10720;2003).

An earlier trial, led by Curt Freed of the University of Colorado Health Sciences Center in Denver, also found that patients did not benefit as a group from fetal tissue transplants (C. R. Freed et al. N. Engl. J. Med. 344, $710-719 ; 2001)$. And both trials found that the procedure caused some patients to suffer jerky involuntary movements, or dyskinesias, as a side effect. More than half of the patients in the latest trial had dyskinesias, compared with $15 \%$ of those in the earlier trial.

The results may have implications for other research using aborted fetal tissue and, perhaps, for future therapies that might use laboratory-grown stem cells to replace defective tissue. Some researchers fear that the negative results will reduce support for the politically controversial stem-cell therapies.

Researchers say that previous trials of fetal cell transplants for Parkinson's disease have been encouraging, as they have worked in some patients. But they feel that they cannot proceed with the technique until they work out how to prevent dyskinesias."Unless we resolve this, it will have a tremendous negative impact on this and other issues in stem-cell research," Olanow says.

After Freed's study, scientists thought that the dyskinesias were caused by overactive neurons. But Olanow found hints that the opposite is true - poorly functioning transplants could be the cause. Olanow and others say that it is crucial to define what makes the transplants function well. Work with neurons grown from stem cells could offer clues, they add, because such labderived cells would contain fewer impurities than fetal tissue.

Another question raised by the latest trial is whether the transplants are being inactivated by the immune system. Olanow's team found some evidence to suggest that an immunological reaction is destroying or disabling the tissue grafts. Such evidence had not been found in previous trials.

Neurologist Olle Lindvall of the University

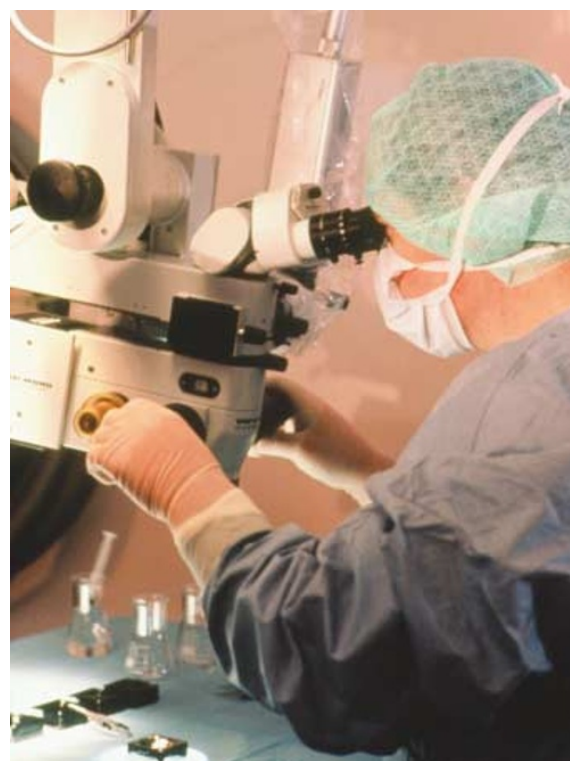

Clinical results cast doubt on the use of fetal cells, being collected here, to treat Parkinson's.

of Lund in Sweden, who is leading a 15-year study of fetal transplants for Parkinson's disease, remains strongly supportive of the transplant idea. But he agrees that the trials raise a number of questions that must be answered by lab work before further clinical trials are done.

"Everyone agrees that we don't yet have a method that would make fetal cell transplants competitive as a clinical treatment," he says.

\section{Zoologists prime traps for California wildlife survey}

\section{Jonathan Knight, San Francisco}

Zoologists in California are repeating an 80-year-old ecological survey of the Sierra Nevada as part of a scheme to measure the effect of human activity on the state's wildlife. The first phase of the project, which

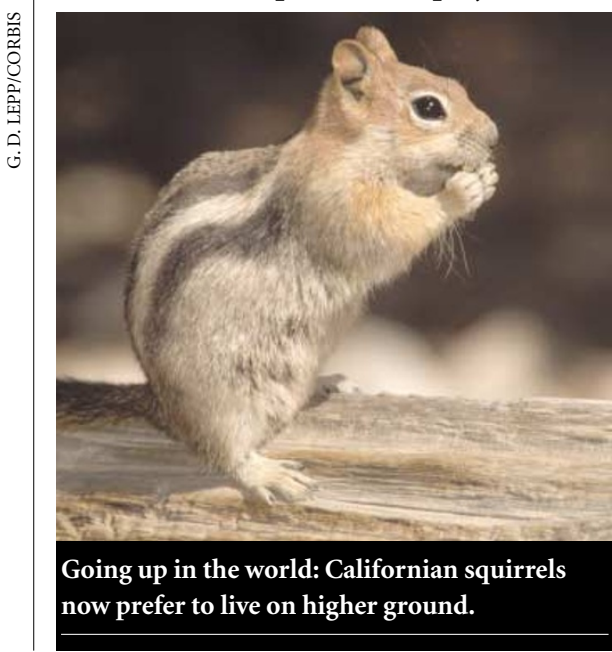

takes place in Yosemite National Park, is also expected to help guide the region's policy for dealing with forest fires.

From 1914 to 1920, the biologist Joseph Grinnell led one of the most extensive wildlife surveys ever conducted in the western United States. His team collected tens of thousands of animal specimens, took about 2,000 photographs, and produced some 13,000 pages of meticulous notes that are still used by biologists today.

Yosemite contains one-fifth of Grinnell's original survey sites, and this summer it once again played host to wildlife survey teams. The US National Park Service has commissioned biologists at the Museum of Vertebrate Zoology at the University of California, Berkeley, to do the work.

Whereas Grinnell relied mainly on the snaptrap - an oversized mousetrap that kills instantly - museum zoologist Craig Moritz, the head of the project, and his team are using live-trapping methods. A few animals will be kept as specimens; the rest will be counted and released.

The team has already found some changes from Grinnell's findings. Several small mammals, such as squirrels, now seem to be living at higher elevations than they used to. One possibility is that warmer average temperatures have driven them higher; another is that fire suppression has caused a build-up of undergrowth and pushed these species uphill.

Berkeley zoologist David Wake, the team's amphibian expert, hopes that the survey will lead to the discovery of new species of salamander. Grinnell's party discovered the first Californian species, the Mount Lyell salamander (Hydromantes platycephalus), in Yosemite. Wake suspects that Yosemite is crawling with salamanders - but Grinnell was less interested in amphibians, and no one has looked carefully since his time.

Moritz hopes to revisit all of Grinnell's survey sites, which range throughout California from the mountains to the coast. "Yosemite will be our benchmark," he says. 